\title{
Effect of temperature and female weight on reproductive performance of two Nile tilapia (Oreochromis niloticus) populations
}

\author{
Ahmed. F. Fath El-Bab; Mohamed. E. Farag; Ashraf, A. Ramadan \\ and Amal, S. Hassan
}

Central Laboratory for Aquaculture Research, Abbassa, Egypt. Agricultural Research center.

\begin{abstract}
$\mathrm{T}$ he present study aimed to investigate the effect of temperature and female weight on reproductive performance of Nile tilapia. Reproductive performances of Oreochromis niloticus broodstock from two populations (Kafr Elshiek and Abbassa) were examined in hapas held in concreat tankes through three months (May, June and July 2010) in one spawning season at Abbassa (CLAR). A total of150 females $(291.94,385.68 \& 455.68 \mathrm{~g})$ and 75 males $(300.148,300.25-300.3 \mathrm{~g})$ from Kafr Elshiek and 150 females $(292.5,387.280$ \& $456.22 \mathrm{~g}$ ) and 75 males (300.254-300.44 g) from Abbassa farm were assigned to 6 haps in 2 concrete ponds $\left(75 \mathrm{~m}^{2}\right)$ at a density of 50 females and 25 males per hapa ( $3 \times 8 \times 1 \mathrm{~m}$ ie $24 \mathrm{~m}^{3}$ water volume). Fish were exposed to different levels of water temperature ranging from $26.2^{\circ} \mathrm{C}$ to $29.6^{\circ} \mathrm{C}$ during the three months.

The result showed that Nile tilapia begins to give fries at water temperature of $26.2 \pm 3.6{ }^{\circ} \mathrm{C}$ and the highest reproduction activity in Abbassa population was recorded at the temperature of $26.2 \pm 3.6{ }^{\circ} \mathrm{C}$. Female gave maximum average number of fries ( $3.03 \pm 0.59$ per gram body weight) in May. While, the reproductive activity was maximum in Kafer El-Shakh population at the temperature of $29.6 \pm 2.65^{\circ} \mathrm{C}$. Female gave maximum average number of fries $(2.99 \pm 0.94$ fries per gram body weight) in June. The spawning percentage increased during May in Abbassa and kafer El-Shakh $(91.63 \pm 0.027 \& 91.34 \pm$ $2.5 \%$ respectively) more than other months and the females (400 g) of Abbassa population gave the highest fries number $(1025 \pm 16.29$ fries / female / month $)$ in May at average water temperature of $26.16^{\circ} \mathrm{C}$ and air humidity $44.9 \%$. While, females $(300 \mathrm{~g})$ of Kafer El-Shakh population gave the highest fries number $(1021 \pm 65.28$ fries / female / month $)$ in June at average water temperature $29.6{ }^{\circ} \mathrm{C}$ and air humidity $47.23 \%$. The highest relative fecundity increased with the decrease in female body weight. Female of Kafer El-Shiek population with low body weight $(300 \mathrm{~g})$ showed more relative fecundity $(5.32 \pm 0.218$ fries $/ \mathrm{g}$ body weight) in June. Also, female of Abbassa population with low body weight $(300 \mathrm{~g})$ have more relative fecundity (5.24 \pm 0.0014 fries/g body weight) in May. On the other hand, female of Abbassa population with high body weight (500 g) have small relative fecundity ( $1.44 \pm 0.42$ fries/g body weight) in July. While,
\end{abstract}


female of Kafer El-Shiek population with high body weight (500 g) have lower relative fecundity ( $2.34 \pm 0.22$ fries/g body weight) in July.

Average number of fry production per spawn was $983.07 \pm 51.5$ fries / female for Kafer El-Shiek population in June when water temperature was $29.6{ }^{\circ} \mathrm{C}$. While, average number of fries production per spawn was $979.33 \pm 50.28$ fries / female for Abbassa population in May when water temperature was $26.16{ }^{\circ} \mathrm{C}$. The result showed that the reporoductive performance of Orochromis niloticus could be maximized by holding broodstock under natural photoperiod in water temperature above $26.16^{\circ} \mathrm{C}$, and the optimal reporoductive performance occures through summer season during May and June. Females with height body weight ( 400 and $500 \mathrm{~g}$ ) gave fries in first generation age 30 days with high body weight in Abbassa ( $0.44 \& 0.43$ g respectively) and females with height body weight $(500 \mathrm{~g})$ give fries in first generation age 30 days with high body weight in Kafer El-Shiek populations $(0.43 \mathrm{~g})$. At the optimal water temperature range from 26 to $29^{\circ} \mathrm{C}$, females with the $300 \mathrm{~g}$ body weight started to spawn first and have more relative fecundity than high body weight and water temperature affected merely spawning frequency, but not the number of fries produced per spawn.

Key words: Reproductive performance, relative and absolute fecundity,Oreochromis niloticus, water temperature, two Populations.

\section{INTRODUCTION}

Tilapia species are very important either natural or cultured in Egyptian freshwater ecosystems. Economic importance of Tilapia is constantly increasing for their fast growth, disease resistance, different feeding habits and palatability (Dagzie, 1982). Tilapia researchers world-wide have concluded that one of the most important requirements for the advancement of Tilapia culture is the development of systems for mass production of seed (free-swimming fry, sac fry and eggs released from the female's mouth) Hughes and Behrends (1983).

Tilapias were second to the carps in weight harvested from culture ponds (Lovshin, 1997). The Nile tilapia, Oreochromis niloticus, is the most widely cultured tilapia in the world because of its rapid growth, late age of sexual maturity and planktivorous feeding habits (Gonzalez, 1997). Oreochromis niloticus is considered as one of the most commercial and common freshwater fish species. It constitutes a considerable part in the annual fish production of the Northern Delta Lakes of Egypt (Shakweer and Abbas, 2006).

Rising temperature to $20^{\circ} \mathrm{C}$ or higher triggers the spawning operations of Tilapia, which start in April or May (Mires, 1983). In the Delta area of Egypt, spawning of Tilapia extends from April to November with a peak in early summer (El-Saby, 1951). Tilapia culture is hindered by reproductive characteristics of its main species. Excessive reproduction in culture ponds reduces the growth rate of adult fish, and reduces marketable size production. 
The low fecundity of Tilapia can make the production of adequate numbers of fingerlings difficult. Tilapia can reproduce in concrete tanks, (Badawy, 1993). Also, he reported that the number of eggs per spawn may differ among species and strains, but within species the larger the female the greater the number of fry produced.

Watanable et al. (1995) reported that the variations in water temperatures within an ecological range can markedly influence development rates and survival of prefeeding larve. Also, El-Naggar et al. (2000) reported that the incubation period tended to be short with increasing water temperature. Eggs of Oreochromis niloticus tended to hatch after 3 to 7 days, depending on temperature and its interaction with protein level and photoperiod. They added that the average hatching period was $6,5.4$ and 3.4 days for incubation temperature of $18-19,20-23$ and $24-27$, respectivly. Also they said that only water temberature, out of the crude protein and photoperiod had a significant effect on the duration of yolk-sac absorbation.

Smith (1996) studied the reproductive success and fry survival of red tilapia with genetic components from $O$. niloticus, $O$. aureus and $O$. mossambicus to pure $O$. niloticus. He reported that no significant difference was found in reproductive performance and in fry survival during sex reversal between the red tilapia and Nile tilapia. Nile tilapia females yielded 2,701 fry and red females 2,718 fry per kilogram of body weight per 13- to 19-day spawning cycle. An average of $80 \%$ and $77 \%$ of the Nile and red tilapia fry, respectively, survived the 14- to 28-day sex reversal period.Devlin and Nagahama (2002) found that sex determination in fish is a very flexible process with respect to evolutionary patterns observed among genera and families, and within individuals is a subject to modification by external factors. These influences can affect the fate of both somatic and germ cells within the primordial gonad, and include the action of genetic, environmental (e.g. temperature), behavioural, and physiological factors.

$\mathrm{Su}$ et al. (2008) reported that the genetic correlations of reproductive traits with body weight in rainbow trout at ages prior to 252 days were not significantly different from zero, while those with body weight at ages from 252 to 364 days were significantly greater than zero and increased with increasing age. The range of estimated genetic correlations between reproductive traits and body weight at ages from 252 to 364 days was from $0.18 \pm 0.08$ to $0.29 \pm 0.06$; for egg size, for egg number, from $0.21 \pm 0.08$ to $0.32 \pm 0.06$; for egg volume, from $0.28 \pm 0.08$ to $0.45 \pm 0.06$ and for post-spawning weight, $0.25 \pm 0.11$ to $0.61 \pm 0.08 \mathrm{~g}$. As a whole, the genetic correlations between reproductive traits and body weight during the first year were favorable, allowing positive genetic improvement in both body weight and reproductive traits.

The objective of this study was to evaluate the effects of different populations origin, water temperature, female brood fish age and brood fish 
weight on the production of fries in hapa held in concrete ponds in one spawning season.

\section{I- Breeding systems}

\section{MATERIAL AND METHODS}

Broodstock of Nile tilapia (Orochromis niloticus) were collected from different fish farms Sedy Salm City, Kafer El-Shiek Governorate (75 males $300.148-300.3 \mathrm{~g}$ and 150 females with three different sizes 291.94, 385.68 \& $455.68 \mathrm{~g}$ ). Also, the same numbers of Nile tilapia was collected from Abbassa farm, Sharkia Governorate ( 75 males $300.254-300.44 \mathrm{~g}$ and 150 females with three different sizes $292.5,387.280 \& 456.22 \mathrm{~g}$ body weight. Fish were stocked at a sex ratio of 1 male : 2 females in 6 hapas held in 2 concert ponds $\left(75 \mathrm{~m}^{2}\right)$ at a density of 50 females and 25 males per hapa $(3 \times 8 \times 1 \mathrm{~m})$.

The water depth was maintained at about $70 \mathrm{~cm}$. Water was changed at a rate of $10 \%$ every third day. The experiment lasted 4 months during the spawning season (May, June \& July 2010) in Central Laboratory for Aquaculture Research, Abbassa, Egypt. Agricultural Research center (CLAR).

Fish were exposed to water temperature naturally from $26.2{ }^{\circ} \mathrm{C}$ to $29.6{ }^{\circ} \mathrm{C}$ and air humidity ranged from $44.903-56.935 \%$ and fed on a containing diet 32 $\%$ protein and $3139.5 \mathrm{Kcal} / \mathrm{Kg}$ metabolizable energy (ME) for male and female twice daily at a rate of $2.5 \%$ biomass weight/day.

Female broodstock were checked for spawning after 14 day from stocking by using net mesh pore $1 \mathrm{~mm}$ at the edge of the hapa in the morning. After about 21 days collection of fries and numbering in nursery net enclosures (hapas) we usually made of plastic mosquito netting (mesh pore $1 \mathrm{~mm}$ ). Hapas are very easy to manage; because fry cannot escape harvesting. For fry collection hapas sizes $1 \times 1 \mathrm{~m}$ with a depth of $1 \mathrm{~m}$ were suspended on concert pond.

Fries of each location classified in 9 hapas $(1 \times 1 \times 1 \mathrm{~m})$ supported in concert pond $\left(75 \mathrm{~m}^{2}\right)$ each hapa contain 100 fries and fed diets $40 \%$ protein and 2748.5 $\mathrm{Kcal} / \mathrm{Kg}(\mathrm{ME})$ three times daily $(9.00 \mathrm{am}, 1.00 \mathrm{pm}$ and $5.00 \mathrm{pm})$ at a rate of $20 \%$ body weight/day.

The water quality parameters of the three concrete ponds showed that ponds have the same ecological conditions were in the following: -
Oxygen (ppm)
Alkalinity $\mathrm{mg}\left(\mathrm{CaCo}_{3}\right) / \mathrm{L}$
$\mathrm{NH}_{4} \mathrm{mg} / \mathrm{L}$
$10.56 \pm 1.54$
$365.5 \pm 18.5$
$0.075 \pm 0.006$

Relative fecundity was calculated in relation to total number of fries per gram body weight of females present in that hapa and the spawning percentages were calculated in relation to total number of fries in one spawn per total number of fries in season x100.

\section{II- Statistical analysis:}

The statistical analysis of data was carried out by applying the computer program SAS (1996). The differences among means were tested for significant 
according to Duncan, (1955). The following model was used in statistical analysis:

$$
\mathrm{Xijk}=\mu+\alpha \mathrm{i}+\beta \mathrm{j}+\gamma \mathrm{k}+(\alpha \beta) \mathrm{ij}+(\alpha \gamma) \mathrm{ik}+(\beta \gamma) \mathrm{jk}+(\alpha \beta \gamma) \mathrm{ijk}+\mathrm{e} \mathrm{ijkl}
$$

Where: Xijk $=$ the $1^{\text {th }}$ observation for the $\mathrm{k}^{\text {th }}$ month, $\mathrm{j}^{\text {th }}$ female body weight and $i^{\text {th }}$ population; $\mu=$ overall mean; $\alpha i=$ the effect of $i^{\text {th }}$ population; $\beta j=$ the effect of $j^{\text {th }}$ female body weight; $\gamma \mathrm{k}=$ the effect of $\mathrm{k}^{\text {th }}$ month; $\alpha \beta \mathrm{ij}=$ the effect of interaction between population and female body weight; $+\alpha \gamma$ ik $=$ the effect of interaction between population and month; $\beta \gamma \mathrm{jk}=$ the effect of interaction between female body weight and month; $\alpha \beta \gamma \mathrm{ijk}=$ the effect of interaction between population, female body weight and month and e ijkl = Random error.

\section{RESULTS AND DISCUSSION}

In the present study, the reproductive performances of parents and growth performances of its fries were used to identify the two populations of Nile tilapia (Oreochromis niloticus) which collected from two locations i.e Kafer El-Shiek and Abbassa. A suitable temperature and controlled photoperiod permit a reasonably close prediction of ovulation time (Shelton, 1999). In the present study, Nile tilapia (Oreochromis niloticus) begins to give fries at water temperature $26.2 \pm 3.6{ }^{\circ} \mathrm{C}$ (Table 1 ).

As presented in (Table 1), averages of water temperatures were found to be $26.1 ; 29.6$ and $29.3{ }^{\circ} \mathrm{C}$ and humidity $44.9 ; 47.2 ; 56.9 \%$ during May; June and July months respectively.

Table 1: Water temperature $\left({ }^{\circ} \mathrm{C}\right)$ and air moisture $(\%)$ during spawning months.

\begin{tabular}{|c|c|c|c|c|c|c|}
\hline \multirow{2}{*}{ Item } & \multicolumn{2}{|c|}{ May } & \multicolumn{2}{c|}{ Jun } & \multicolumn{2}{c|}{ Jul } \\
\cline { 2 - 7 } & Tem. $\left({ }^{\circ} \mathrm{C}\right)$ & Mos. $(\%)$ & Tem. $\left({ }^{\circ} \mathrm{C}\right)$ & Mos. $(\%)$ & Tem. $\left({ }^{\circ} \mathrm{C}\right)$ & Mos. $(\%)$ \\
\hline Mean & 26.12 & 44.9 & 29.6 & 47.2 & 29.3 & 56.9 \\
\hline \pm SD & 3.18 & 9.76 & 2.65 & 8.51 & 1.56 & 5.71 \\
\hline
\end{tabular}

Total egg weight per female (g) and egg weight (g) per gm of body weight:

Total egg weight per female (EWF) and egg weight per gm of body weight (EWG) as affected by population are presented in Table (2). As described in this table the averages of (EWF) were 11.55 and $13.49 \mathrm{~g}$ and averages of (EWG) as affected with population were 0.3 and $0.04 \mathrm{~g}$ for the two population Abbassa and Kafer El-Shiek, respectively. These results indicate the EWF for population of Kafer El-Shiek was higher than obtained in population of Abbassa. The same trend was also observed for EWG. The differences between means were significant $(\mathrm{P}<0.05)$.

With regard to the effect of body weight of females on EWF results of (Table, 2) showed that, EWF was 11.68, 13.55 and 12.1g and EWG was0.047, 0.035 and $0.03 \mathrm{~g}$ for the three female weight groups 300,400 and $500 \mathrm{~g}$ 
respectively. And the differences among due to the effect of three female weights were significant $(\mathrm{P}<0.05)$.

Table 2: Least squares mean and standard error for some factors affecting egg weight $(\mathrm{g}) /$ fish and egg weight $(\mathrm{g}) / \mathrm{gm}$ of fish body weight

\begin{tabular}{|c|c|c|c|}
\hline Variable & No. & Egg weight/Fish & Egg weight/Gm. F \\
\hline \multicolumn{4}{|l|}{ Population (P) } \\
\hline Abbassa & 450 & $11.55 \pm 3.10 \mathrm{~b}$ & $0.03 \pm 0.01 \mathrm{~b}$ \\
\hline Kafer El-Shiek & 450 & $13.34 \pm 3.106 \mathrm{a}$ & $0.04 \pm 0.01 \mathrm{a}$ \\
\hline \multicolumn{4}{|l|}{ Effect of weight (W) } \\
\hline 300 & 300 & $11.68 \pm 3.10 \mathrm{~b}$ & $0.047 \pm 0.01 \mathrm{a}$ \\
\hline 400 & 300 & $13.55 \pm 3.10 \mathrm{a}$ & $0.035 \pm 0.001 b$ \\
\hline 500 & 300 & $12.1 \pm 3.10 \mathrm{~b}$ & $0.030 \pm 0.001 \mathrm{c}$ \\
\hline \multicolumn{4}{|l|}{ Effect of month (M) } \\
\hline May & 300 & $14.24 \pm 5.85 \mathrm{a}$ & $0.041 \pm 0.02 \mathrm{a}$ \\
\hline June & 300 & $13.52 \pm 5.85 b$ & $0.043 \pm 0.02 \mathrm{a}$ \\
\hline July & 300 & $9.58 \pm 5.85 \mathrm{c}$ & $0.029 \pm 0.02 b$ \\
\hline \multicolumn{4}{|l|}{$\mathbf{P}^{*} \mathbf{W}^{*} \mathbf{M}$} \\
\hline $\mathrm{P} 1 * \mathrm{~W} 1 * \mathrm{M} 1$ & 50 & $12.346 \pm 6.7 b$ & $0.052 \pm 0.04 \mathrm{a}$ \\
\hline $\mathrm{P} 1 * \mathrm{~W} 1 * \mathrm{M} 2$ & 50 & $14.240 \pm 6.7 \mathrm{~b}$ & $0.057 \pm 0.04 \mathrm{a}$ \\
\hline $\mathrm{P} 1 * \mathrm{~W} 1 * \mathrm{M} 3$ & 50 & $10.870 \pm 6.7 \mathrm{c}$ & $0.044 \pm 0.04 \mathrm{~b}$ \\
\hline $\mathrm{P} 1 * \mathrm{~W} 2 * \mathrm{M} 1$ & 50 & $16.078 \pm 6.7 \mathrm{a}$ & $0.036 \pm 0.04 \mathrm{c}$ \\
\hline $\mathrm{P} 1 * \mathrm{~W} 2 * \mathrm{M} 2$ & 50 & $15.300 \pm 6.7 \mathrm{a}$ & $0.045 \pm 0.04 \mathrm{a}$ \\
\hline $\mathrm{P} 1 * \mathrm{~W} 2 * \mathrm{M} 3$ & 50 & $11.630 \pm 6.7 \mathrm{c}$ & $0.033 \pm 0.04 \mathrm{c}$ \\
\hline $\mathrm{P} 1 * \mathrm{~W} 3 * \mathrm{M} 1$ & 50 & $13.313 \pm 6.7 \mathrm{ab}$ & $0.035 \pm 0.04 \mathrm{c}$ \\
\hline $\mathrm{P} 1 * \mathrm{~W} 3 * \mathrm{M} 2$ & 50 & $14.730 \pm 6.7 \mathrm{~b}$ & $0.044 \pm 0.04 \mathrm{~b}$ \\
\hline $\mathrm{P} 1 * \mathrm{~W} 3 * \mathrm{M} 3$ & 50 & $11.570 \pm 6.7 \mathrm{c}$ & $0.025 \pm 0.04 \mathrm{~d}$ \\
\hline $\mathrm{P} 2 * \mathrm{~W} 1 * \mathrm{M} 1$ & 50 & $13.500 \pm 6.7 \mathrm{c}$ & $0.052 \pm 0.04 \mathrm{a}$ \\
\hline $\mathrm{P} 2 * \mathrm{~W} 1 * \mathrm{M} 2$ & 50 & $11.740 \pm 6.7 \mathrm{c}$ & $0.047 \pm 0.04 \mathrm{ab}$ \\
\hline $\mathrm{P} 2 * \mathrm{~W} 1 * \mathrm{M} 3$ & 50 & $7.400 \pm 6.7 \mathrm{~d}$ & $0.030 \pm 0.04 \mathrm{~d}$ \\
\hline $\mathrm{P} 2 * \mathrm{~W} 2 * \mathrm{M} 1$ & 50 & $16.530 \pm 6.7 \mathrm{a}$ & $0.036 \pm 0.04 \mathrm{c}$ \\
\hline $\mathrm{P} 2 * \mathrm{~W} 2 * \mathrm{M} 2$ & 50 & $12.890 \pm 6.7 \mathrm{a}$ & $0.037 \pm 0.04 \mathrm{c}$ \\
\hline $\mathrm{P} 2 * \mathrm{~W} 2 * \mathrm{M} 3$ & 50 & $8.864 \pm 6.7 \mathrm{~d}$ & $0.025 \pm 0.04 \mathrm{~d}$ \\
\hline $\mathrm{P} 2 * \mathrm{~W} 3 * \mathrm{M} 1$ & 50 & $13.650 \pm 6.7 \mathrm{~b}$ & $0.035 \pm 0.04 \mathrm{c}$ \\
\hline P2*W3*M2 & 50 & $12.210 \pm 6.7 \mathrm{~b}$ & $0.027 \pm 0.04 \mathrm{~d}$ \\
\hline $\mathrm{P} 2 * \mathrm{~W} 3 * \mathrm{M} 3$ & 50 & $7.140 \pm 6.7 \mathrm{~d}$ & $0.015 \pm 0.04 \mathrm{e}$ \\
\hline
\end{tabular}

+ Means with the same letter in each column are not significantly differences $(\mathrm{p}<0.05)$.

Concerning the effect of month averages of EWF and EWG for months May, June and July were found to be14.24, 13.52 and $9.58 \mathrm{~g}$ for EWF and 0.041, 0.042 and $0.029 \mathrm{~g}$ for EWG, respectively (Table 2). The analysis of variance of results indicate that the highest EWF and EWG were significant $(\mathrm{P}<0.05)$ in May followed by June and July. These differences may be due to the differences in 
environmental conditions such as temperature, water quality and natural food availability fro parent stock.

Khater (1985) found that mean production of eggs and fry per $\mathrm{Kg} / \mathrm{Female}$ body weight of Ghana tilapia strain was higher than those of Egypt and Ivory Coast. This difference was due to the greater frequency of spawning per female in Ghana strain relative to Egypt and Ivory Coast strains. Shaikh and Hafeez (1993) and Ghania, (2008) revealed that long photoperiod-warm temperature accelerated gametogenic progress in the pre spawning season. Short photoperiod, warm temperature had inhibitory or regression effect in most seasons. Warm temperature in the spawning season, stimulated spawning and low temperature inhibited it regardless of photoperiod. Low temperature in long and short photoperiod initiated gonadal recrudescence in both sexes on Cyprinid fish, Cyprinion watsoni. The reproduction activity of Tilapia begins at $22^{\circ} \mathrm{C}$, and the optimal temperature range is $25-29^{\circ} \mathrm{C}$ (Shmuel and Yoel, 1975) and Watanable, et al. (1995).

El-Naggar et al. (2000) reported that spawning percentage for Oreochromis niloticus averaged 10 and $34 \%$ for natural photoperiod treatments when water temperature increased to $19-21^{\circ} \mathrm{C}$. The most reproductive period coincided with a rise in water temperature from 22 to $27{ }^{\circ} \mathrm{C}$. Farag (2003) observed that female body weight play an important role in the beginning of spawning.

Results of Table (2) show that interaction among populations, female weight and months were significant $(\mathrm{P}<0.05)$ thus the females of Abbassa population at weight $(400 \mathrm{~g})$ at May and June recorded the highest EWF and EWG.

\section{Absolute and relative fecundity:}

Concerning the effect of population, regardless of female body weights and months of absolute and relative fecundity for population Abbassa and Kafer El-Shiek were found to be 1042.59, and 1223.78 for absolute fecundity and 82.26 and 85.67 for relative fecundity, respectively (Table 3) for two populations Abbassa and Kafer El-Shiek. The differences between means were significant $(\mathrm{P}<0.05)$.

With regard to effect of body weight of females on absolute and relative fecundity were $1089.58,1201.25$ and 1108.73 and the relative fecundity were $4.34,3.33$ and 2.43 for three weight females 300,400 and $500 \mathrm{~g}$, respectively. Analyses of variance show that body weight of females had a significant effect on both absolute and relative fecundity.

Hashem and El-Agamy (1977) revealed that, fecundity is a function related to length, weight and age of different fish species and it increased with increase in these parameters. Watanabe and Kuo (1985) reported that, absolute fecundity increase by using large and old tilapia Bhujel (2006) indicated that, absolute fecundity is related to body weight, while De Silva (1986) found that, absolute fecundity is related to body length. 
With regard to the effect of month on absolute and relative fecundity, Table (3) showed that, absolute fecundity was $1245.98,1274.08$ and 879.5 for three months. The relative fecundity in the same table was 3.62,3.82 and 2.67 for three months May, June and July, respectively.

Table 3: Least squares mean and standard deviation for some factors affecting absolute and relative fecundity.

\begin{tabular}{|c|c|c|c|}
\hline Variable & No. & Absolute fecundity & Relative fecundity \\
\hline \multicolumn{4}{|l|}{ Population (P) } \\
\hline Abbassa & 450 & $1042.59 \pm 18.67 \mathrm{~b}$ & $3.16 \pm 0.06 \mathrm{~b}$ \\
\hline Kafer El-Shiek & 450 & $1223.78 \pm 18.76 \mathrm{a}$ & $3.37 \pm 0.06 \mathrm{a}$ \\
\hline \multicolumn{4}{|l|}{ Effect of weight (W) } \\
\hline 300 & 300 & $1089.58 \pm 18.67 b$ & $4.34 \pm 0.06 \mathrm{a}$ \\
\hline 400 & 300 & $1201.25 \pm 18.67 \mathrm{a}$ & $3.33 \pm 0.06 \mathrm{~b}$ \\
\hline 500 & 300 & $1108.73 \pm 18.67 b$ & $2.43 \pm 0.06 \mathrm{c}$ \\
\hline \multicolumn{4}{|c|}{ Effect of month (M) } \\
\hline May & 300 & $1245.98 \pm 22.18 \mathrm{a}$ & $3.62 \pm 0.07 \mathrm{~b}$ \\
\hline June & 300 & $1274.08 \pm 22.18 \mathrm{a}$ & $3.82 \pm 0.07 \mathrm{a}$ \\
\hline July & 300 & $879.5 \pm 22.18 b$ & $2.67 \pm 0.07 \mathrm{c}$ \\
\hline \multicolumn{4}{|l|}{$\mathbf{P}^{*} \mathbf{W}^{*} \mathbf{M}$} \\
\hline $\mathrm{P} 1 * \mathrm{~W} 1 * \mathrm{M} 1$ & 50 & $1192.660 \pm 42.47 \mathrm{c}$ & $4.151 \pm 0.14 \mathrm{a}$ \\
\hline $\mathrm{P} 1 * \mathrm{~W} 1 * \mathrm{M} 2$ & 50 & $1330.000 \pm 42.47 \mathrm{a}$ & $5.320 \pm 0.14 \mathrm{a}$ \\
\hline $\mathrm{P} 1 * \mathrm{~W} 1 * \mathrm{M} 3$ & 50 & $1035.000 \pm 42.47 \mathrm{c}$ & $4.158 \pm 0.14 \mathrm{a}$ \\
\hline $\mathrm{P} 1 * \mathrm{~W} 2 * \mathrm{M} 1$ & 50 & $1321.840 \pm 42.47 \mathrm{a}$ & $3.483 \pm 0.14 \mathrm{~b}$ \\
\hline $\mathrm{P} 1 * \mathrm{~W} 2 * \mathrm{M} 2$ & 50 & $1409.200 \pm 42.47 \mathrm{a}$ & $4.030 \pm 0.14 \mathrm{a}$ \\
\hline $\mathrm{P} 1 * \mathrm{~W} 2 * \mathrm{M} 3$ & 50 & $1090.0 \pm 42.47 \mathrm{~cd}$ & $3.120 \pm 0.14 \mathrm{bc}$ \\
\hline $\mathrm{P} 1 * \mathrm{~W} 3 * \mathrm{M} 1$ & 50 & $1236.500 \pm 42.47 \mathrm{~b}$ & $2.675 \pm 0.14 \mathrm{c}$ \\
\hline $\mathrm{P} 1 * \mathrm{~W} 3 * \mathrm{M} 2$ & 50 & $1353.800 \pm 42.47 \mathrm{a}$ & $2.880 \pm 0.14 \mathrm{c}$ \\
\hline $\mathrm{P} 1 * \mathrm{~W} 3 * \mathrm{M} 3$ & 50 & $1043.000 \pm 42.47 \mathrm{c}$ & $2.340 \pm 0.14 \mathrm{c}$ \\
\hline $\mathrm{P} 2 * \mathrm{~W} 1 * \mathrm{M} 1$ & 50 & $1183.620 \pm 42.47 \mathrm{c}$ & $5.240 \pm 0.14 \mathrm{a}$ \\
\hline $\mathrm{P} 2 * \mathrm{~W} 1 * \mathrm{M} 2$ & 50 & $1128.200 \pm 42.47 \mathrm{c}$ & $4.520 \pm 0.14 \mathrm{a}$ \\
\hline $\mathrm{P} 2 * \mathrm{~W} 1 * \mathrm{M} 3$ & 50 & $668.000 \pm 42.47 \mathrm{e}$ & $2.670 \pm 0.14 \mathrm{c}$ \\
\hline $\mathrm{P} 2 * \mathrm{~W} 2 * \mathrm{M} 1$ & 50 & $1322.840 \pm 42.47 \mathrm{a}$ & $3.476 \pm 0.14 \mathrm{~b}$ \\
\hline $\mathrm{P} 2 * \mathrm{~W} 2 * \mathrm{M} 2$ & 50 & $1265.600 \pm 42.47 \mathrm{~b}$ & $3.620 \pm 0.14 \mathrm{~b}$ \\
\hline $\mathrm{P} 2 * \mathrm{~W} 2 * \mathrm{M} 3$ & 50 & $796.000 \pm 42.47 \mathrm{e}$ & $2.270 \pm 0.14 \mathrm{c}$ \\
\hline $\mathrm{P} 2 * \mathrm{~W} 3 * \mathrm{M} 1$ & 50 & $1218.400 \pm 42.47 \mathrm{~b}$ & $2.673 \pm 0.14 \mathrm{c}$ \\
\hline $\mathrm{P} 2 * \mathrm{~W} 3 * \mathrm{M} 2$ & 50 & $1155.68 \pm 42.47 \mathrm{c}$ & $2.570 \pm 0.14 \mathrm{c}$ \\
\hline $\mathrm{P} 2 * \mathrm{~W} 3 * \mathrm{M} 3$ & 50 & $645.000 \pm 42.47 \mathrm{e}$ & $1.440 \pm 0.14 \mathrm{~d}$ \\
\hline
\end{tabular}

+ Means with the same letter in each column are not significantly differences $(p<0.05)$. 


\section{Hatchability percentage:}

Concerning the effect of population, regardless of female body weights and month, averages of hatchability percentage for population Abbassa and Kafer El-Shiek were found 82.26 and $85.67 \%$ for two population, $85.46,82.64$ and $83.8 \%$ for three weight of females 300,400 and $500 \mathrm{~g}$ and $90.83,82.48$ and 78.59 for three months May, June and July, respectively, Table (4). These results indicated that, were found to be, and. And the differences in hatchability percentage attributed to populations, female weights and months were significant $(\mathrm{P}<0.05)$. These results are in agreement with those obtained by Gunasekera et al., (2006) who found that, hatchability percentage decreased with increasing female body weight. Morsy (2001) found that, hatchability percentage increased with increase in body weight.

The differences between averages of hatchability percentage duo to the effect of the interaction among the three factors were significant $(\mathrm{P}<0.05)$.

\section{Fry number per fish (FN/F):}

Concerning the effect of population, regardless of female body weights and month, averages of fry number per fish were found to be 695.7 and 810.29 fry/fish for two population Abbssa and Kafer El-Shiek, 738.66, 776.48 and 743.86 fry/fish for three weight of females 300, 400 and 500 and 932, 853.03 and 473.4 fry/fish for three months May, June and July, respectively. three weight of females and months were found to be $\mathrm{g}$. These results indicated that, fry number increased by increasing in body weight, Table (4). And the differences between means were significant $(\mathrm{P}<0.005)$. Thorp (2004) found that, larger eggs produce significantly larger swim-up fry of tilapia. Morsy (2001) reported that, by increasing in body weight black carp increase in the fry number produced by females of black carp.

The differences between averages of fry number per fish duo to the effect of the interaction among the three factors were significant $(\mathrm{P}<0.05)$.

\section{Fry body weight:}

Concerning the effect of population, regardless of female body weights and month, averages of fry body weight after 2 days were $0.02 \mathrm{~g}$ for three factors affecting. After 10 days the averages of body weight of fry were 0.035 and $0.036 \mathrm{~g}$ for two populations, $0.036,0.035$ and $0.034 \mathrm{~g}$ for three weights off females and, $0.036,0.035$ and $0.035 \mathrm{~g}$ for three months. After 20days averages of body weight of fry were 0.126 and $0.125 \mathrm{~g}$ for two populations Abbassa and Kafer El-Shiek, 0.126, 0.125 and $0.125 \mathrm{~g}$ for three weights off females and 0.126, 0.126 and $0.123 \mathrm{~g}$ for three months. Table (5) also showed that, the averages of body weight of fry after 30 days were 0.41 and $0.39 \mathrm{~g}$ for two populations, 0.42 , 0.4 and $0.39 \mathrm{~g}$ for three weights off females and $0.43,0.42$ and $0.4 \mathrm{~g}$ for three months. 
The differences between averages of fry body weight duo to the effect of the interaction among the three factors were significant $(\mathrm{P}<0.05)$.

Table 4: Least squares mean and standard deviation for some factors affecting Fry number/fish and Hatchability percentage.

\begin{tabular}{|c|c|c|c|}
\hline Variable & No. & Fry number/fish & Hatchability\% \\
\hline \multicolumn{4}{|l|}{ Population (P) } \\
\hline Abbassa & 450 & $695.71 \pm 14.46 b$ & $82.26 \pm 0.19 b$ \\
\hline Kafer El-Shiek & 450 & $810.29 \pm 14.46 a$ & $85.67 \pm 0.19 a$ \\
\hline \multicolumn{4}{|c|}{ Effect of weight (W) } \\
\hline 300 & 300 & $738.66 \pm 18.12 \mathrm{a}$ & $85.46 \pm 0.23 a$ \\
\hline 400 & 300 & $776.48 \pm 18.12 a$ & $82.64 \pm 0.23 c$ \\
\hline 500 & 300 & $743.86 \pm 18.12 a$ & $83.8 \pm 0.23 b$ \\
\hline \multicolumn{4}{|l|}{ Effect of month (M) } \\
\hline May & 300 & $932.83 \pm 18.12 \mathrm{a}$ & $90.83 \pm 0.24 a$ \\
\hline June & 300 & $853.03 \pm 18.12 b$ & $82.48 \pm 0.24 b$ \\
\hline July & 300 & $473.4 \pm 18.12 c$ & $78.59 \pm 0.24 \mathrm{c}$ \\
\hline \multicolumn{4}{|l|}{$P^{*} W^{*} M$} \\
\hline $\mathrm{P} 1 * \mathrm{~W} 1 * \mathrm{M} 1$ & 50 & $823.980 \pm 43.7 \mathrm{~b}$ & $90.240 \pm 0.42 b$ \\
\hline P1*W1*M2 & 50 & $1021.000 \pm 43.7 \mathrm{a}$ & $89.120 \pm 0.42 \mathrm{~b}$ \\
\hline P1*W1*M3 & 50 & $586.000 \pm 43.7 d$ & $79.850 \pm 0.42 \mathrm{e}$ \\
\hline P1*W2*M1 & 50 & $936.280 \pm 43.7 a$ & $90.360 \pm 0.42 b$ \\
\hline P1*W2*M2 & 50 & $981.000 \pm 43.7 a$ & $83.020 \pm 0.42 b c$ \\
\hline $\mathrm{P} 1 * \mathrm{~W} 2 * \mathrm{M} 3$ & 50 & $514.000 \pm 43.7 d$ & $80.450 \pm 0.42 c$ \\
\hline P1*W3*M1 & 50 & $897.160 \pm 43.7 \mathrm{~b}$ & $91.340 \pm 0.42 \mathrm{a}$ \\
\hline $\mathrm{P} 1 * \mathrm{~W} 3 * \mathrm{M} 2$ & 50 & $947.000 \pm 43.7 a$ & $84.938 \pm 0.42 b$ \\
\hline $\mathrm{P} 1 * \mathrm{~W} 3 * \mathrm{M} 3$ & 50 & $586.000 \pm 43.7 d$ & $81.730 \pm 0.42 \mathrm{bc}$ \\
\hline P2*W1*M1 & 50 & $911.000 \pm 43.7 \mathrm{ab}$ & $91.240 \pm 0.42 \mathrm{a}$ \\
\hline $\mathrm{P} 2 * \mathrm{~W} 1 * \mathrm{M} 2$ & 50 & $725.000 \pm 43.7 \mathrm{c}$ & $82.160 \pm 0.42 b c$ \\
\hline P2*W1*M3 & 50 & $365.000 \pm 43.7 \mathrm{e}$ & $80.150 \pm 0.42 b c$ \\
\hline $\mathrm{P} 2 * \mathrm{~W} 2 * \mathrm{M} 1$ & 50 & $1025.000 \pm 43.7 \mathrm{a}$ & $91.630 \pm 0.42 a$ \\
\hline $\mathrm{P} 2 * \mathrm{~W} 2 * \mathrm{M} 2$ & 50 & $749.000 \pm 43.7 \mathrm{c}$ & $75.480 \pm 0.42 d$ \\
\hline $\mathrm{P} 2 * \mathrm{~W} 2 * \mathrm{M} 3$ & 50 & $453.400 \pm 43.7 \mathrm{e}$ & $74.872 \pm 0.42 \mathrm{e}$ \\
\hline $\mathrm{P} 2 * \mathrm{~W} 3 * \mathrm{M} 1$ & 50 & $1002.000 \pm 43.7 \mathrm{a}$ & $90.160 \pm 0.42 b$ \\
\hline $\mathrm{P} 2 * \mathrm{~W} 3 * \mathrm{M} 2$ & 50 & $695.000 \pm 43.7 \mathrm{c}$ & $80.140 \pm 0.42 d$ \\
\hline $\mathrm{P} 2 * \mathrm{~W} 3 * \mathrm{M} 3$ & 50 & $336.000 \pm 43.7 \mathrm{e}$ & $74.504 \pm 0.42 \mathrm{e}$ \\
\hline
\end{tabular}

+ Means with the same letter in each column are not significantly differences $(\mathrm{p}<0.05)$. 
Table 5: Least squares mean and standard deviation for some factors affecting body weight of Nile tilapia fry.

\begin{tabular}{|c|c|c|c|c|c|}
\hline Variable & No. & 2days & 10days & 20days & 30days \\
\hline \multicolumn{6}{|l|}{ Population $(\mathrm{P})$} \\
\hline Abbassa & 450 & $0.02 \pm 0.04$ & $0.035 \pm 0.06 \mathrm{~b}$ & $0.126 \pm 0.05 \mathrm{a}$ & $0.41 \pm 0.06 \mathrm{a}$ \\
\hline Kafer El-Shiek & 450 & $0.02 \pm 0.04$ & $0.036 \pm 0.06 \mathrm{a}$ & $0.125 \pm 0.05 b$ & $0.39 \pm 0.06 \mathrm{~b}$ \\
\hline \multicolumn{6}{|l|}{ Effect of weight (W) } \\
\hline 300 & 300 & $0.02 \pm 0.05$ & $0.036 \pm 0.07 \mathrm{a}$ & $0.126 \pm 0.07 \mathrm{a}$ & $0.42 \pm 0.07 \mathrm{a}$ \\
\hline 400 & 300 & $0.02 \pm 0.05$ & $0.035 \pm 0.07 \mathrm{~b}$ & $0.125 \pm 0.07 \mathrm{~b}$ & $0.4 \pm 0.071 \mathrm{~b}$ \\
\hline 500 & 300 & $0.02 \pm 0.05$ & $0.035 \pm 0.07 \mathrm{~b}$ & $0.125 \pm 0.07 \mathrm{~b}$ & $0.39 \pm 0.07 \mathrm{c}$ \\
\hline \multicolumn{6}{|l|}{ Effect of month (M) } \\
\hline May & 300 & $0.02 \pm 0.05$ & $0.036 \pm 0.07 \mathrm{a}$ & $0.126 \pm 0.07 b$ & $0.43 \pm 0.07 \mathrm{a}$ \\
\hline June & 300 & $0.02 \pm 0.05$ & $0.035 \pm 0.07 \mathrm{~b}$ & $0.126 \pm 0.07 b$ & $0.42 \pm 0.07 \mathrm{~b}$ \\
\hline July & 300 & $0.02 \pm 0.05$ & $0.034 \pm 0.07 \mathrm{c}$ & $0.130 \pm 0.07 \mathrm{a}$ & $0.40 \pm 0.07 \mathrm{c}$ \\
\hline \multicolumn{6}{|l|}{$\mathrm{P}^{*} \mathrm{~W}^{*} \mathrm{M}$} \\
\hline $\mathrm{P} 1 * \mathrm{~W} 1 * \mathrm{M} 1$ & 50 & $0.02 \pm 0.13$ & $0.036 \pm 0.14 \mathrm{a}$ & $0.130 \pm 0.14 \mathrm{a}$ & $0.46 \pm 0.13 \mathrm{a}$ \\
\hline $\mathrm{P} 1 * \mathrm{~W} 1 * \mathrm{M} 2$ & 50 & $0.02 \pm 0.13$ & $0.035 \pm 0.14 \mathrm{~b}$ & $0.130 \pm 0.14 \mathrm{a}$ & $0.40 \pm 0.13 \mathrm{c}$ \\
\hline $\mathrm{P} 1 * \mathrm{~W} 1 * \mathrm{M} 3$ & 50 & $0.02 \pm 0.13$ & $0.033 \pm 0.14 \mathrm{c}$ & $0.122 \pm 0.14 \mathrm{e}$ & $0.44 \pm 0.13 \mathrm{a}$ \\
\hline $\mathrm{P} 1 * \mathrm{~W} 2 * \mathrm{M} 1$ & 50 & $0.02 \pm 0.13$ & $0.033 \pm 0.14 \mathrm{c}$ & $0.125 \pm 0.14 \mathrm{c}$ & $0.42 \pm 0.13 \mathrm{~b}$ \\
\hline $\mathrm{P} 1 * \mathrm{~W} 2 * \mathrm{M} 2$ & 50 & $0.02 \pm 0.13$ & $0.035 \pm 0.14 b$ & $0.123 \pm 0.14 \mathrm{~d}$ & $0.43 \pm 0.13 b$ \\
\hline $\mathrm{P} 1 * \mathrm{~W} 2 * \mathrm{M} 3$ & 50 & $0.02 \pm 0.13$ & $0.034 \pm 0.14 b c$ & $0.126 \pm 0.14 b c$ & $0.40 \pm 0.13 \mathrm{c}$ \\
\hline $\mathrm{P} 1 * \mathrm{~W} 3 * \mathrm{M} 1$ & 50 & $0.02 \pm 0.13$ & $0.033 \pm 0.14 \mathrm{c}$ & $0.127 \pm 0.14 b$ & $0.39 \pm 0.13 \mathrm{~d}$ \\
\hline $\mathrm{P} 1 * \mathrm{~W} 3 * \mathrm{M} 2$ & 50 & $0.02 \pm 0.13$ & $0.036 \pm 0.14 \mathrm{a}$ & $0.130 \pm 0.14 \mathrm{a}$ & $0.41 \pm 0.13 b c$ \\
\hline $\mathrm{P} 1 * \mathrm{~W} 3 * \mathrm{M} 3$ & 50 & $0.02 \pm 0.13$ & $0.032 \pm 0.14 \mathrm{~d}$ & $0.126 \pm 0.14 b c$ & $0.38 \pm 0.13 \mathrm{e}$ \\
\hline $\mathrm{P} 2 * \mathrm{~W} 1 * \mathrm{M} 1$ & 50 & $0.02 \pm 0.13$ & $0.036 \pm 0.14 \mathrm{a}$ & $0.126 \pm 0.14 b c$ & $0.44 \pm 0.13 \mathrm{a}$ \\
\hline $\mathrm{P} 2 * \mathrm{~W} 1 * \mathrm{M} 2$ & 50 & $0.02 \pm 0.13$ & $0.035 \pm 0.14 \mathrm{~b}$ & $0.124 \pm 0.14 \mathrm{c}$ & $0.41 \pm 0.13 b c$ \\
\hline $\mathrm{P} 2 * \mathrm{~W} 1 * \mathrm{M} 3$ & 50 & $0.02 \pm 0.13$ & $0.036 \pm 0.14 \mathrm{a}$ & $0.125 \pm 0.14 \mathrm{c}$ & $0.45 \pm 0.13 \mathrm{a}$ \\
\hline $\mathrm{P} 2 * \mathrm{~W} 2 * \mathrm{M} 1$ & 50 & $0.02 \pm 0.13$ & $0.034 \pm 0.14 b c$ & $0.129 \pm 0.14 \mathrm{a}$ & $0.43 \pm 0.13 \mathrm{~b}$ \\
\hline $\mathrm{P} 2 * \mathrm{~W} 2 * \mathrm{M} 2$ & 50 & $0.02 \pm 0.13$ & $0.035 \pm 0.14 \mathrm{~b}$ & $0.128 \pm 0.14 \mathrm{a}$ & $0.37 \pm 0.13 \mathrm{~d}$ \\
\hline $\mathrm{P} 2 * \mathrm{~W} 2 * \mathrm{M} 3$ & 50 & $0.02 \pm 0.13$ & $0.036 \pm 0.14 \mathrm{a}$ & $0.121 \pm 0.14 \mathrm{e}$ & $0.41 \pm 0.13 b c$ \\
\hline $\mathrm{P} 2 * \mathrm{~W} 3 * \mathrm{M} 1$ & 50 & $0.02 \pm 0.13$ & $0.034 \pm 0.14 b$ & $0.130 \pm 0.14 \mathrm{a}$ & $0.39 \pm 0.13 \mathrm{~d}$ \\
\hline $\mathrm{P} 2 * \mathrm{~W} 3 * \mathrm{M} 2$ & 50 & $0.02 \pm 0.13$ & $0.037 \pm 0.14 \mathrm{a}$ & $0.125 \pm 0.14 \mathrm{c}$ & $0.42 \pm 0.13 \mathrm{~b}$ \\
\hline $\mathrm{P} 2 * \mathrm{~W} 3 * \mathrm{M} 3$ & 50 & $0.02 \pm 0.13$ & $0.034 \pm 0.14 \mathrm{bc}$ & $0.127 \pm 0.14 b$ & $0.41 \pm 0.13 b c$ \\
\hline
\end{tabular}

+ Means with the same letter in each column are not significantly differences $(\mathrm{p}<0.05)$.

\section{CONCLUSION}

Based on the obtained results, it cold be concluded that, Kafer El-Shiek population were better than of Abbassa population for traits, egg weight per fish, egg weight per gm fish, absolute and relative fecundity, hatchability $\%$ and fry number per fish. But the population of Abbassa was better from body weigh of Nile tilapia fry. 
Female weights $300 \mathrm{~g}$ were better than female weight 400 and $500 \mathrm{~g}$ for traits, egg weight per gm fish, relative fecundity, hatchability $\%$ and body weight of fry. Female weight $400 \mathrm{~g}$ is better than female weight 300 and $500 \mathrm{~g}$ in traits egg weight per fish, absolute fecundity fry number per fish.

May was better than June and July for traits, egg weight per fish, fry number per fish, hatchability \% and body weight of fry. But June is a better month than May and July in traits egg weight per gm fish, absolute and relative fecundity.

\section{REFERENCES}

Badawy, E.A. (1993). Biological studies on Tilapia species as a major component of the Egyptian fish farming system. Ph. D. Thesis, Fac. of Sci., Zagazig Univ.. 222pp.

Bhujel, R. C. (2006). A review of strategies for the management of Nile tilapia Oreochromis niloticus brood fish in seed production systems, especially haps-based system. Aquacult., 181: 37-59.

Dagzie, M. (1982). Species combination in Tilapia culture. Aquacult., 27: 295299.

De Silva, S. S. (1986). Reproductive biology of Oreochromis mossambicus population of man-mode lakes in Srilanka: a comparative study. Aquacult. And Fisheries Management, 17: 31-47.

Devlin, R. H. and Nagahama, Y. (2002). Sex determination and sex differentiation in fish: an overview of genetic, physiological, and environmental influences. Aquacult., 208 (3-4): 191-364.

Duncan, D.B. (1955). Multiple ranges and multiple F-Test. Biometric, 11:1-42.

El-Naggar, G.O.; El-Nady, M. A.; Kamar, M.G. and Al-Kobaby, A.I. (2000). Effect of photoperiod, dietary protein and temperature on reproduction in Nile tilapia (Oreochromis niloticus). In the 21st Century Proceedings from the Fifth International Symposium on Tilapia Aquacult. Hotel Sofitel Rio Palace Convention Center Rio Die Janeiro-RJ, Brazil September 3-7:352358.

El-Saby, M.K. (1951). The lake fisheries of Egypt. Proc. Un. Sci. Conf. Conserv. Unil. Resource. 7: 126-130. 
Farag, M. S. (2003). Reproductive performance of Oreochromis niloticus through three seasons on earthen ponds. Egypt. J. Aquat. Biol. \& fish., 7(4): $263-282$.

Ghania, M. I. M. (2008). Studies on genetic development within tilapia populations in Egypt. Al-Azhar Univ., Fac. of Agricult. Department of Animal Production.

Gonzalez, C. E. (1997). La Piscicultura en Colombia: Technologia de Punta en El Departamento del Valle del Cauca". Pp. 78-84 in D. E. Alston, B. W. Green and H. C. Clifford, editors, IV symposium on aquacult. in Central America: focusing on shrimp and tilapia, 22-24 April, Tegucigalpa, Honduras. Asociacion Nacional de Acuicultores de Honduras and the Latin American Chapter of the World Aquacult. Society.

Gunasekera, R. M., K. F. and Lam, T. J. (1996). Effect of dietary protein level on spawning performance and amino acid composition of egg of Nile tilapia (Oreochromis niloticus L.). Aquacult., 146:12-134.

Hashem, M. T. and El-Agamy, A. (1977). Effect of fishing and maturation on the barbus bynni population of the Nozha Hydrome. Bull Inst. Ocean and fish A. R. E. 7:137-151.

Hughes, D.G. and Behrends, L.L. (1983). Mass production of Tilapia nilotica seed in suspended net enclosures. International Symposium on Tilapia in Aquacult.. Proceedings Nazareth Israel, May 8-13: 394-401.

Khater, A.A. (1985): Identification and comparison of three Tilapia nilotica populations for selected aquacultureal traits. Doctoral dissertation, Auburn Univ., Alabama, USA.

Lovshin, L. L. (1997). Worldwide Tilapia Culture". in Anais do I Workshop International de Aquicult., October 15-17, 96-116 . Sao Paulo, Brazil.

Mires, D. (1983). A technical evolution of tilapia culture. 317-329. International symposium on tilapia in aquaculture, Proceedings 624P Tel Aviv Univ., Israel. 
Morsy, K. A. I. (2001). Studies on carp propagation in Egypt. M. Sc. Thesis, Fac. of Agricult. Zagazig Univ. Banha Branch.

Shaikh, S.A. and Hafeez, M.A. (1993). Effects of photoperiod and temperature on gonadal response in the cyprinid fish, Cyprinion watsoni. PAK. J. Zool., 25 (3): 233-241.

Shakweer, L. M. and Abbas, M. M. (2006). Effect of sex on the concentration levels of some trace metals in Oreochromis niloticus of lake Edku and Sardinella aurita of the Mediterranian waters, Egypt. Bull. Nat. Inst. of Oceanogr. \& Fish., 22: 121-141.

Shelton, W.L. (1999). Management of finfish reproduction for aquaculture. CRC Rev.Aquat. Sci., 1: 497-535.

Shmuel, R. and Yoel P. (1975). Induced spawning and africial incubation of Tilapia. Aquacult., 5: 315-321.

Snedecor, G.W. (1971). "Statistical Methods" $14^{\text {th }}$. Ed. Imes, Iwa. The Iowa State Univ. Press, 593 pp.

Su, G.S.; Liljedahl, L.E. and Graham, A. E. G. (2008). Genetic correlations between body weight at different ages and with reproductive traits in rainbow trout. Aquacult., 213(1-4): 85-94.

Thorpe, J. E. (1984). Development rate, fecundity and egg size in Atlantic Salmon (Salmo salar L.). Aquacult., 43:289-306.

Watanable, W. O. and C. M. Kuo (1985). Observation on the reproductive performance of Nile tilapia Oreochromis niloticus in the laboratory aquaria at variance salinities. Aquacult., 49:323.

Watanable, W. O.; Lee C. S.; Ellis, S. C. and Ellis, E. P. (1995). Hatchery study of the Effects of Temperature on Eggs and Yolksac Larvae of the Nassau Grouper, (Epinephelus striatus). Aquacult., 136: 141-147. 